\title{
DIREITOS FUNDAMENTAIS E ACESSO À ÁGUA POTÁVEL
}

Dellton Ribeiro Brasil

Pós-Doutorando pelo CENoR da Faculdade de Direito da Universidade de Coimbra, Portugal. Pós-Doutoramento em Democracia e Direitos Humanos pela FDUC. Doutor em Direito pela Universidade Gama Filho do Rio de Janeiro - RJ. Mestre em Direito pela Faculdade Milton Campos - MG. Professor do Instituto de Ensino Superior Presidente Tancredo de Almeida Neves (IPTAN) e da Faculdade de Direito de Conselheiro Lafaiete (FDCL). Lattes: http://lattes.cnpq.br/1342540205762285. E-mail: deilton.ribeiro@terra.com.br

\section{Resumo}

O presente artigo pretende analisar o acesso à água potável como direito fundamental, dentro do contexto do princípio da dignidade humana na construçáo de um Estado de Direito Ambiental. Reconhecer o acesso à água potável como direito fundamental consiste em atribuir ao Estado o dever de garantir um mínimo essencial à sadia qualidade de vida das presentes e futuras geraçóes. Tais garantias se concretizam pelo fornecimento de água, respeitados os padrôes de potabilidade, a gestão hídrica, a tutela administrativa e judicial das águas e pela conscientização da importância da atuação conjunta entre poder público e sociedade para a preservação dos recursos hídricos contextualizada dentro da sociedade de risco.

\section{Palavras-chave}

Direitos fundamentais; Sociedade de risco; Acesso à água potável; Mínimo existencial.

\section{Resumen}

Este trabajo analiza el acceso al agua potable como un derecho fundamental en el contexto del principio de la dignidad humana en la construcción de un Estado de Derecho Ambiental. Reconocer el acceso al agua como un derecho fundamental, es dar al Estado el deber de garantizar uma calidad esencial minima de vida saludable para las generaciones presentes y futuras, obtenidos por el suministro de agua, respetando las normas de potabilidad, la gestión del agua, protección administrativa y judicial de las aguas y la conciencia de la importancia de una acción conjunta entre el gobierno y la sociedad para la preservación de los recursos hídricos en el contexto de la sociedad del riesgo. 


\section{Palabras clave}

Derechos fundamentales; Sociedad del riesgo; Acceso al agua potable; Mínimo existencial.

\section{Introdução}

Para Carson (2010, p. 47), de todos os nossos recursos naturais, a água tornou-se o mais precioso. A maior parte da superfície da Terra é coberta por mares que a envolvem; no entanto, em meio a toda essa fartura, ainda queremos mais. Por um estranho paradoxo, a maior parte da abundante água da Terra não pode ser utilizada para a agricultura, indústria ou para o consumo humano em virtude da elevada quantidade de sais marinhos; dessa forma, a maioria da população mundial passa ou é ameaçada por uma escassez crítica. Em uma era em que o ser humano esqueceu suas origens e está cego até mesmo para suas necessidades mais básicas de sobrevivência, a água, assim como outros recursos, tornou-se uma vítima da indiferença humana.

Viola (2010, p. 47) ainda acrescenta que, a combinação de crescimento da população mundial, consumo generalizado de energia fóssil e desenvolvimento tecnológico dentro de um paradigma carbono intensivo tem sido a causa principal do processo de aquecimento global. As principais manifestações das mudanças climáticas são os fenômenos climáticos extremos - ondas de calor e frio mais intensas e prolongadas, secas, inundações, tormentas e furacóes mais severos - e a retração de geleiras das montanhas, do Ártico e da Antártida, com impacto sobre o nível do mar imbricam-se em situaçóes de vulnerabilidade ambiental.

Lovelock (2006, p. 15-19) salienta que estamos abusando tanto da Terra que ela poderá se insurgir e retornar ao estado quente de 55 milhóes de anos atrás e se isso acontecer, a maioria de nós e nossos descendentes morreremos. Ainda que cessássemos neste instante de arrebatar novas terras e águas de Gaia para a produção de alimentos e combustíveis e parássemos de envenenar o ar, a Terra levaria mais de mil anos para se recuperar do dano já infligido.

Para Wolkmer; Paulitsch (2013, p. 257) e Glasenapp; Cruz (2011, p. 116), o atual modelo civilizatório, caracterizado pela complexidade das relaçóes interpostas entre desenvolvimento econômico, direito e sustentabilidade, possibilita a institucionalização do Estado de Direito Ambiental. Complementando este pensamento, Ost (1997, p. 355) argumenta sobre a necessidade de uma compreensão mais global no que se refere à questão ambiental e à sua regulação, preceituando que:

[...] do local (a "minha" propriedade, a "minha" herança) conduz ao global (o patrimônio comum do grupo, da nação, da humanidade); do simples 
(tal espaço, tal indivíduo, tal facto físico), conduz ao completo (o ecossistema, a espécie, o ciclo); de um regime jurídico ligado em direitos e obrigaçóes individuais (direitos subjectivos de apropriação e obrigaçóes correspondentes), conduz a um regime que toma em consideração os interesses difusos (os interesses de todos, incluindo os das gerações futuras) e as responsabilidades colectivas; [...]

No mesmo sentido, Canotilho (2011, p. 21-31) defende que:

[...] o Estado de Direito, hoje, só é Estado de Direito se for um Estado protector do ambiente e garantidor do direito ao ambiente; mas o Estado ambiental e ecológico só será Estado de Direito se cumprir os deveres de juridicidade impostos à atuação dos poderes públicos.

Portanto, a proteção socioambiental impóe, sob todos seus prismas, um tratamento inovador, o que repercute também na perspectiva das políticas e das práticas do Estado e para além do Estado, visto que não se submetem aos limites territoriais da ordem jurídica moderna e às suas estratégias (GLASENAPP; CRUZ, 2011, p. 75). Nessa perspectiva, a Constituição propôe um novo significado para a já clássica noção de Constituição Econômica, atribuindo outros objetivos, cuja concretização é agora considerada relevante para o desenvolvimento de um significado diferenciado de ordem econômica, conforme atesta Ayala (2012, p. 297). Esse novo significado proposto pela Constituiçáo à ordem econômica a define nos termos de uma "economia social e ecológica de mercado" (HÄBERLE, 2003, p. 240-244).

A Constituição da República Federativa do Brasil contemplou o novo significado. Os atributos econômicos e ecológicos estão reunidos pela Constituição Brasileira na condição de princípios gerais da atividade econômica (art. 170, incisos II e VI, CF), admitindo que todos são relevantes para a finalidade de se atribuir valor a determinado bem, in verbis:

Art. 170. A ordem econômica, fundada na valorização do trabalho humano e na livre iniciativa, tem por fim assegurar a todos existência digna, conforme os ditames da justiça social, observados os seguintes princípios:

(...)

II - propriedade privada;

(...)

VI - defesa do meio ambiente, inclusive mediante tratamento diferenciado conforme o impacto ambiental dos produtos e serviços e de seus processos de elaboração e prestação (Redação dada pela Emenda Constitucional no 42, de 19.12.2003).

A proteçáo da utilidade econômica dos recursos naturais por intermédio da propriedade privada constitui apenas uma das referências que fundamentam a ordem econômica 
nacional. Não é a única e, tampouco, a principal. A obrigação de defesa do meio ambiente e a função social da propriedade condicionam a forma de valoração dos bens para a finalidade de apropriação. Definem uma nova modalidade de apropriação de bens, que complementa o sentido econômico, fazendo com que seja integrada à dimensão econômica uma dimensão que poderia ser chamada de dimensão de apropriação social. Qualquer relação de apropriação deve permitir o cumprimento de duas funçôes distintas: uma individual (dimensão econômica da propriedade) e uma coletiva (dimensão socioambiental da propriedade).

Em suma, somente a propriedade privada que cumpra a sua função social possui proteção constitucional, seu descumprimento importa a imposição de uma sanção: a expropriação compulsória (art. 182, $\$ 4^{\circ}$, III e art. 184, “caput”, CF). Esta é suportada pelo proprietário exatamente em razáo do exercício irresponsável do direito e da gestáo inadequada dos recursos naturais (AYALA, 2012, p. 299-300).

Nesse contexto, emerge o paradigma do Estado de Direito Ambiental. Ele incorpora uma nova dimensão para contemplar o elenco dos objetivos fundamentais do Estado de Direito contemporâneo: a proteção do meio ambiente, que se articula dialeticamente com as demais dimensóes consagradas no decurso do processo do Estado de Direito (PUREZA, 1996, p. 27).

Sob essa ótica, o Estado de Direito Ambiental é definido como a forma de Estado que se propóe a aplicar o princípio da solidariedade social e econômica com o objetivo de alcançar um desenvolvimento sustentável, orientado a buscar a igualdade substancial entre os cidadãos, por meio do controle jurídico do uso racional dos recursos naturais, o que legitima e dá suporte ao processo de judicialização das políticas públicas ambientais, quando verificada a omissão ou necessidade de atividade prestacional pelo poder público (BELLVER-CAPELLA, 1994, p. 248).

\section{A Água no Contexto da Crise}

Sendo assim, a escassez e o mau uso da água doce são fatores de grande e crescente risco ao desenvolvimento sustentável e à proteção do meio ambiente. A água doce é um recurso finito e essencial para sustentar a vida, o desenvolvimento e o meio ambiente. Já que a água sustenta a vida, o gerenciamento efetivo dos recursos hídricos demanda uma abordagem holística, ligando desenvolvimento social com o econômico e proteção dos ecossistemas naturais. Gerenciamento efetivo liga os usos da terra aos da água nas áreas de drenagem ou aquífero de águas subterrâneas (Declaração de Dublin, princípio 1º).

A água tem valor econômico em todos os usos competitivos e deve ser reconhecida como um bem econômico. No contexto deste princípio, é vital reconhecer inicialmente 
o direito básico de todos os seres humanos do acesso ao abastecimento e saneamento a custos razoáveis. $\mathrm{O}$ erro no passado de não reconhecer o valor econômico da água tem levado ao desperdício e usos deste recurso de forma destrutiva ao meio ambiente. O gerenciamento da água como bem de valor econômico é um meio importante para atingir o uso eficiente e equitativo, e o incentivo à conservação e proteção dos recursos hídricos (Declaração de Dublin, princípio $4^{\circ}$ ).

No âmbito do direito brasileiro, a água passou a ser considerada como bem de domínio público dotado de valor econômico, nos termos do art. 1º, I e II da Lei n o 9433/97 (Lei dos recursos hídricos). Por sua vez, o Decreto no 24643 de 10 de julho de 1934 que decretou o Código de Águas, no Livro II que se refere ao aproveitamento das águas em seu art. 34 preceitua que "é assegurado o uso gratuito de qualquer corrente ou nascente de águas, para as primeiras necessidades da vida, se houver caminho público que a torne acessível”. E o art. 35 ressalva que "se não houver este caminho, os proprietários marginais não podem impedir que os seus vizinhos se aproveitem das mesmas para aquele fim, contanto que sejam indenizados do prejuízo que sofrerem com o trânsito pelos seus prédios”.

Também o art. 109 reza que "a ninguém é licito conspurcar ou contaminar as águas que não consome, com prejuízo de terceiros”. E como consequência, "os trabalhos para a salubridade das águas serão executados à custa dos infratores, que, além da responsabilidade criminal, se houver, responderão pelas perdas e danos que causarem e pelas multas que lhes forem impostas nos regulamentos administrativos" (art. 110). Esse dispositivo foi complementado pelo art. 54, inciso III da Lei no 9605 de 12 de fevereiro de 1998 que dispóe sobre as sançóes penais e administrativas derivadas de condutas e atividades lesivas ao meio ambiente, in verbis:

Art. 54. Causar poluição de qualquer natureza em níveis tais que resultem ou possam resultar em danos à saúde humana, ou que provoquem a mortandade de animais ou a destruição significativa da flora.

Pena - reclusão, de um a quatro anos, e multa.

$\$ 2$ o Se o crime:

III - causar poluição hídrica que torne necessária a interrupção do abastecimento público de água de uma comunidade.

Pena - reclusão, de um a cinco anos.

Ainda dentro desse arcabouço legislativo, destacam-se a Lei no 9985 de 18 de julho de 2000 que institui o Sistema Nacional de Unidades de Conservação da Natureza que tem como objetivos enumerados no seu art. $4^{\circ}$ "proteger e recuperar recursos hídricos e edáficos"; a Lei no 10257 de 10 de julho de 2001 (Estatuto da Cidade) que tem determina a ordenação e controle do uso do solo, de forma a evitar a poluição e a degradação ambiental (art. 2º, VI, alínea g). 
O Código Civil de 2002, no seu art. 1228, $\$ 1^{\circ}$, bem como o Estatuto da Cidade (Lei no 10257/01), no art. 1º, parágrafo único, também fortalecem o princípio da função ecológica da propriedade, vez que:

Art. 1228.

$\$ 1^{\circ} \mathrm{O}$ direito de propriedade deve ser exercido em consonância com as suas finalidades econômicas e sociais e de modo que sejam preservados, de conformidade com o estabelecido em lei especial, a flora, a fauna, as belezas naturais, o equilíbrio ecológico e o patrimônio histórico e artístico, bem como evitada a poluição do ar e das águas.

Art. $1^{\circ}$ da Lei no $10257 / 01$. Na execução da política urbana, de que tratam os arts. 182 e 183 da Constituição Federal, será aplicado o previsto nesta Lei.

Parágrafo único. Para todos os efeitos, esta Lei, denominada Estatuto da Cidade, estabelece normas de ordem pública e interesse social que regulam o uso da propriedade urbana em prol do bem coletivo, da segurança e do bem-estar dos cidadãos, bem como do equilíbrio ambiental.

Nesse sentido, o Superior Tribunal de Justiça no REsp 1109778/SC, 2a Turma, DJ 04.05.2011 reconheceu a função ecológica da propriedade, em julgamento paradigmático, como se extrai de trecho do voto do Relator, Ministro Herman Benjamin:

A faculdade de "usar, gozar e dispor da coisa" (art. 1228, caput), núcleo econômico do direito de propriedade, está condicionada à estrita observância, pelo proprietário atual, da obrigação propter rem de proteger a flora, a fauna, as belezas naturais, o equilíbrio ecológico e o patrimônio histórico e artístico, bem como evitar a poluição do ar e das águas" (parágrafo único do mesmo art. 1228).

Trata-se, a toda evidência, de exigência que, nos regimes jurídicos contemporâneos, incide sobre os imóveis rurais ou urbanos, que passam a transportar finalidades múltiplas (privadas e públicas, inclusive ecológicas), o que faz com que sua utilidade econômica não se esgote em um único uso, no melhor uso e, muito menos, no mais lucrativo uso.

$\mathrm{Na}$ verdade, a ordem constitucional-legal brasileira não garante ao proprietário e ao empresário o máximo retorno financeiro possível dos bens privados e das atividades exercidas. Exigências de sustentabilidade ecológica na ocupação e utilização de bens econômicos privados não evidenciam apossamento, esvaziamento ou injustificada intervenção pública. Prescrever que indivíduos cumpram certas cautelas ambientais na exploração de seus pertences não é atitude discriminatória, tampouco rompe com o princípio da isonomia, mormente porque ninguém é confiscado do que não lhe cabe no título ou senhorio.

Se o proprietário ou possuidor se sujeita à função social e à função ecológica da propriedade, despropositado alegar perda indevida daquilo que, no regime constitucional 
e legal vigente, nunca deteve, isto é, a possibilidade de utilização completa, absoluta, ao estilo da terra arrasada, da coisa e de suas virtudes naturais. Ao revés, quem assim proceder estará se apoderando ilicitamente (uso nocivo ou anormal da propriedade) de atributos públicos do patrimônio privado (serviços e processos ecológicos essenciais), que são"bem de uso comum do povo", nos termos do art. 225, caput, da Constituição de 1988.

Assim, os mencionados dispositivos do Código Civil e do Estatuto da Cidade consagram o princípio da solidariedade, englobando, também, o meio ambiente ecologicamente equilibrado, uma saudável qualidade de vida, progresso, autodeterminação dos povos e outros direitos difusos. Notadamente, são direitos que transcendem o individual e o coletivo, na medida em que os interesses individuais ou privados se subordinam a interesses da maioria em prol do bem-estar social (LEITE; BELCHIOR, 2014, p. 13).

Por essa razão, consoante Farias (2005, p. 396-403), o valor econômico declarado à água pela legislação de recursos hídricos, torna-a uma mercadoria, embora seja um mecanismo para sua proteção. Esse debate ganhou força no século XXI, quando se aventou sobre a possibilidade de sua equiparação a uma "commodity". Destaca-se que o mercado das águas não se refere, exclusivamente, à exploração da água mineral (envasada), mas, também, à água tratada no que tange ao seu modelo de gerenciamento, abastecimento, saneamento, irrigação, geração de energia, entre outros (DALLA CORTE; PORTANOVA, 2013, p. 106).

Segundo Ferreira (2011, p. 56-57), embora esse princípio aparentemente condicione o acesso à água ao pagamento de um preço razoável, isso não implica que os desprovidos de condiçóes de pagar tal valor, previamente estipulado, ficariam impedidos de usufruir desse recurso. Considerando que o acesso à água potável e ao saneamento constitui direitos humanos, a segurança do abastecimento de água é um aspecto chave na redução da pobreza.

E ainda, pelo disposto na Constituição Federal, as águas passaram a ser consideradas bens dos Estados e da União, pela sua titularidade no art. 20, inciso III e do art. 26, inciso I evidenciando que o legislador constitucional náo inseriu o direito ao acesso a água potável no catálogo específico de direitos e garantias individuais embora seja possível aplicar analogicamente ou implicitamente o art. 225 da Constituição em matéria de água. Nesse mesmo raciocínio, Steigleder (2002, p. 271), preleciona que a Constituição Federal de 1988, no seu art. 225, "caput", alçou o direito ao meio ambiente ecologicamente equilibrado à categoria de direito fundamental da pessoa humana, assim entendido como pressuposto para os igualmente fundamentais direitos à vida e à saúde. $\mathrm{O}$ art. 225 também impóe ao Poder Público o dever de defender o meio ambiente e preservá-lo para as presentes e futuras geraçóes, o que também vem reforçado na Carta Constitucional no art. 23, que trata da competência comum da Uniâo, dos Estados, do Distrito Federal e 
dos Municípios para proteger o meio ambiente e combater a poluição em qualquer das suas formas (inciso V) e preservar as florestas, a fauna e a flora (inciso VII).

\section{A Crise da Água na Sociedade de Risco}

A água é um mineral, composto por dois átomos de hidrogênio e um átomo de oxigênio, que forma um líquido incolor, inodoro, que se constitui parte integrante do meio ambiente que oferece condição essencial para a existência da vida no planeta. Por água potável entende-se,

[...] aquela conveniente para o consumo humano. Isenta de quantidades apreciáveis de sais minerais ou de microorganismos nocivos, diz-se daquela que conserva seu potencial de consumo de modo a não causar prejuízos ao organismo. Potável é a quantidade da água que pode ser consumida por pessoas e animais sem riscos de adquirirem doenças por contaminação (FACHIN; SILVA, 2010, p. 74).

Tundisi; Tundisi (2009, p. 23) salientam que estas características são fundamentais para a água funcionar como substância de grande importância biológica, física e química. A água é chamada de "solvente universal", o que lhe dá propriedades importantes, pois dissolve substâncias e íons. Outra propriedade importante é a "viscosidade", uma medida de resistência da água líquida ao fluxo. A "tensão superficial” resulta da ligação coesiva do hidrogênio na base de cristal líquido. Certos animais e plantas se mantêm na superfície da água utilizando-se desta tensão superficial, que se quebra pela presença de substâncias como detergentes e aumenta com a concentração de sais dissolvidos.

A água também é um recurso estratégico para a humanidade, pois mantém a vida no planeta Terra, sustenta a biodiversidade e a produção de alimentos e suporta todos os ciclos naturais. A água tem, portanto, importância ecológica, econômica e social. Há uma cultura relacionada com a água e um ciclo hidrossocial na interrelação da população humana com as águas continentais e costeiras. Sem água de qualidade adequada, o desenvolvimento econômico-social e a qualidade da vida da população humana ficam comprometidas. As fontes de água doce, superficiais ou subterrâneas, têm sofrido, especialmente nos últimos cem anos, em razão de um conjunto de atividades humanas sem precedentes na história: construção de hidrovias, urbanização acelerada, usos intensivos das águas superficiais e subterrâneas na agricultura e na indústria (TUNDISI; TUNDISI, 2009, p. 8-9).

Para Fachin; Silva (2010, p. 6), dentre os principais problemas ambientais existentes no mundo, o mais preocupante, ou pelo menos um deles, é a escassez da água. Também Pinto (2007, p. 125) salienta que a crise da água é a mais grave prevista para o século XXI, atingindo de alguma forma todos os países e todas as pessoas. Por seu turno, Graf 
(2008, p. 58) acrescenta ainda que essa crise da água caracteriza-se por não se relacionar, exclusivamente, com a quantidade dos recursos hídricos disponíveis para consumo, mas por se referir também à qualidade de tais recursos e ao modo de utilização.

Assim, a crise global da água em seu aspecto quantitativo, relaciona-se com a escassez de recursos hídricos em decorrência da sua distribuição irregular na superfície terrestre, bem como em razão da sua falta de qualidade. Dessa forma, pode-se possuir uma disponibilidade hídrica sustentável, mas, em razão da ausência de condiçóes de potabilidade, a quantidade de água acessível para o consumo restará diminuída. Quanto à crise da água em seu prisma qualitativo, refere-se à degradação dos recursos hídricos, a qual ocorre por diversos motivos, sendo o principal deles a poluição ambiental (VIEGAS, 2012, p. 26-27).

De acordo com o resultado da consulta nacional da Agenda 21 Brasileira (2004, p. 43-44) o balanço hídrico em território brasileiro mostra grande diversidade hidrológica, que varia desde 48,2 1/s/km2 no Atlântico Norte e 34,2 1/s/km2na bacia amazônica, até 2,8 1/s/km2 na região semiárida do Atlântico Leste, 1 até 4,5 1/s/km2na bacia do rio São Francisco.O volume de água subterrânea nos lençóis mais profundos está estimado em $112.000 \mathrm{~km} 3$. Segundo a Associação Brasileira de Águas Subterrâneas, há cerca de 200.000 poços tubulares em exploração; são perfurados cerca de 10.000 poços por ano. Cerca de $61 \%$ da população brasileira se abastece de mananciais de subsuperfície, tais como poços rasos $(6 \%)$, nascentes/fontes $(12 \%)$ e poços profundos $(43 \%)$.

Dessa forma, conforme a Agenda 21 Brasileira (2004, p. 41) é fundamental e indispensável que a sociedade incorpore a visão de que os recursos naturais só estarão disponíveis para a atual e as futuras geraçóes se utilizados de modo racional, compatível com a preservaçáo e o tempo de regeneração e recuperação dos utilizados. Com muita frequência a preservação, a recuperação e a regeneração não atendem às necessidades de reprodução do capital, seja em funçáo do curto prazo que se costuma prever para o retorno dos investimentos, seja porque se exercita outro ritmo, para atender às necessidades geradas pelo crescimento populacional provocando, numa e na outra hipótese,situaçóes que ameaçam espécies e/ou ecossistemas.

Santin; Dalla Corte (2013, p. 24-29) registram que a poluiçáo das águas acarreta maiores investimentos públicos no tratamento de sua qualidade e em saneamento básico, pois os recursos hídricos contaminados causam, diretamente, malefícios à saúde das pessoas. Assim, os níveis atuais de poluição, principalmente no que tange aos recursos hídricos, estão muito concentrados, em especial nos centros urbanos em razão da falta de saneamento básico, infraestrutura e ocupação de áreas irregulares.

Os dados apontados atingem diretamente os direitos humanos à vida digna e à saúde da população, bem como contribui para a crise da água e para outros gravames ambientais, como o efeito estufa e a destruição da camada vegetal. Esse quadro tende a agravar-se 
com a crescente demanda da água na agricultura, na indústria e nos usos domésticos, bem como a partir do aumento da população urbana, principalmente nas periferias das metrópoles, os recursos hídricos passaram a sofrer danos até então não evidenciados no meio social como, por exemplo, problemas sérios pelo despejo de dejetos industriais, de lixo, de enchentes, de esgoto doméstico em rios, córregos e fontes.

Tal situação também é agravada no entendimento de Santos (2011, p. 1) pelo fato de que a contaminação das águas ultrapassa as fronteiras municipais, estaduais e muitas vezes nacionais, atingindo locais distantes da fonte poluidora, o que torna inoperante a tentativa de diminuí-los sem a participação de todos os envolvidos, acrescentando aí a sociedade civil.

Para Santin; Dalla Corte (2013, p. 27-28), analisadas as causas da crise global da água, ela deve ser contextualizada dentro da sociedade de risco, no que se refere aos seus aspectos socioambientais. A sociedade de risco não surgiu de condutas intencionais humanas: é considerada um estágio da modernidade em que os efeitos da industrialização e suas ameaças começam a ganhar forma. Assim, infere-se que é a partir da indefinição dos limites dos riscos e perigos produzidos pela sociedade e pela falibilidade das medidas de segurança reconhecidas pelo organismo social que emergem as principais características da denominada sociedade de risco.

$\mathrm{Na}$ sociedade de risco, os perigos representam as circunstâncias fáticas que sempre ameaçaram a sociedade; enquanto os riscos são considerados aqueles criados artificialmente pelo homem, ou seja: são consequências da escolha do seu estilo de vida ou - numa outra perspectiva - representam o resultado da opção do tipo de desenvolvimento que cada sociedade persegue. Observa-se que os riscos e perigos requerem medidas ou açóes urgentes, de caráter preventivo e repressivo e que a sociedade deve assumir novos contornos ou diretrizes a fim de se maximizar a segurança no âmbito social (BIANCHI, 2010, p. 19-20).

Nesse processo, descreve, como significativo elemento de distinção, a alteração da compreensão dos perigos na medida em que se passa à formulação da concepção de risco, determinando, por fim, a configuração deste e o perfil das respostas institucionais lhe dirigidas no mundo moderno. $\mathrm{Na}$ análise das mudanças apontadas, assumem papel de relevo, dentre os riscos de graves consequências, os riscos ambientais, o que se justifica em face da intensificação recente das possibilidades de ocorrência de catástrofes ecológicas em grande escala, na forma de ameaças globais (BORATTI, 2010, p. 133-134).

Beck (1998, p. 78-80), descreve como significativa a distinção entre as categorias risco e perigo. Perigos ou ameaças sempre estiveram presentes na história da humanidade. Já o risco apresenta-se como conceito próprio da modernidade, uma vez que compreendido como resultado de processos decisórios associados à industrializaçáo, e, portanto, 
justificado racionalmente. $\mathrm{O}$ risco, assim, não seria determinação do destino, mas sim consequência de decisôes fabricadas pelo homem, no curso da modernização técnicocientífica e dinamização do desenvolvimento econômico.

Porém, com a intensificação do processo de industrialização, aceleração do avanço técnico-científico e dinamização do desenvolvimento econômico, surgem dilemas relacionados à origem, alcance, previsão e distribuição dos riscos. As ameaças decorrentes das ações e decisões humanas assumem, então, outras naturezas, escapando ao controle das instituiçôes: incalculabilidade, imprevisibilidade, incontrolabilidade, imperceptibilidade e, até mesmo, dimensão catastrófica, podendo conduzir a sociedade à autodestruição (BECK, 1998, p. 97).

Como consequência, denota-se a falência dos mecanismos de segurança e controle típicos da racionalidade industrial e o reconhecimento da falibilidade da ciência na verificação das ameaças, bem como das instituiçôes em administrá-las. Ou seja, os modelos de causalidade e imputabilidade se mostram ineficazes como mecanismos de percepçáo e análise do risco moderno (BECK, 1998, p. 13). Conduz-se, assim, a sociedade industrial a uma crise ou estado de "autolimitação", ou melhor, um processo de autorreflexão sobre suas próprias premissas. Seria a radicalização da modernidade, ou, em outras palavras, a sociedade torna-se um tema e um problema para si mesma (BECK, 1998, p. 26).

Para Demajorovic (2003, p. 44-45) desde o reconhecimento dos problemas de degradação socioambiental decorrentes da intensificação do processo de industrialização, o debate sobre riscos tem sido primazia daqueles que detêm o conhecimento técnico. Os especialistas concentraram seus esforços em encontrar alternativas para diminuir as possibilidades de acidentes industriais e de contaminação ambiental e no caso da ocorrência efetiva do dano, procuram implementar medidas para mitigar suas conseqüências. No entanto, essas alternativas perdem sua eficácia quando pensamos nas novas características da sociedade de risco. Muitos cientistas e representantes de diversas organizaçóes empresariais utilizam o argumento da incalculabilidade, entendida como incerteza sobre os reais impactos das alteraçôes ambientais no futuro, para impedir ou ao menos postergar açóes mais contundentes no momento presente.

$\mathrm{Na}$ realidade, o processo social de reconhecimento de risco ainda que baseado muito mais em estimativas do que em sua real calculabilidade, forja o desenvolvimento de uma moral ecológica. O consenso criado em torno dos benefícios proporcionados pelas empresas, fundamentado em sua contribuição para o crescimento do emprego e do nível de renda, choca-se com a moral ecológica. Esta não apenas questiona os aspectos econômicos e tecnológicos das açóes empresariais, mas se materializa também em pressóes políticas, em um maior rigor das normas de comando e controle, no aumento dos custos de operação, na maior interferência no processo de tomada de decisão dentro das organizaçóes 
e no reconhecimento, por parte do Poder Judiciário, das demandas de compensação por danos ambientais (DEMAJOROVIC, 2003, p. 45-46).

Dessa forma, o discurso ambiental remodelado assume uma crítica ao próprio processo produtivo - simbolizado pelo consumo excessivo dos recursos naturais, pela elevada geração de resíduos sólidos e pela poluição dos recursos hídricos - fundamentando-se não mais simplesmente nos valores morais, mas na racionalidade técnico-científica, a mesma que possibilitara o desenvolvimento da sociedade industrial (DEMAJOROVIC, 2003, p. 50).

\section{Escassez de Água}

Franca; Cardoso Neto (2006, p. 26-27) classificam a escassez de água em duas categorias: a conjuntural e a estrutural. A escassez conjuntural é aquela decorrente de situaçôes desfavoráveis, naturais ou não. Esse tipo de escassez pode ocorrer por diversos fatores. Algumas situaçóes que podem gerá-la são esporádicas, geralmente de duração não muito longa, e normalmente restritas a regióes muito específicas. Um exemplo comum é a que ocorre em conflitos armados que cerceiam o acesso às fontes de abastecimento hídrico. Uma estiagem extraordinariamente prolongada que se abate sobre uma região normalmente não muito seca, como a que ocorreu no ano passado no sul do Brasil, por exemplo, pode ocasionar uma escassez passageira e localizada, que também pode ser descrita como conjuntural. O combate a esse tipo de escassez consiste no restabelecimento da normalidade da conjuntura adversa, que é, geralmente, pontual e exige que sejam tomadas decisões eficazes e rápidas.

A escassez estrutural se deve a um desequilíbrio entre disponibilidades e prioridades. Uma manifestação desse tipo de escassez é, por exemplo, a que acontece em uma região que tenha optado por quase exaurir seus recursos hídricos sem se importar com os seus usos múltiplos, como ocorreu no vale do rio Murray, na Austrália, em meados do século XIX, onde a irrigação foi tâo intensiva que inviabilizou a navegação no rio, que era o principal meio de transporte usado para escoar a produção, o que acabou fazendo com que toda a atividade agrícola da região entrasse em colapso. Há regióes nas quais tanto a oferta quanto a demanda de água são abundantes, mas a prioridade é favorecer um emprego específico do recurso em detrimento de toda uma multiplicidade de usos. Quando se fala em escassez, não se deve esquecer a que se refere à carência de qualidade satisfatória da água. A podridão dos rios que atravessam as cidades brasileiras é uma escassez estrutural com reflexos imediatos devastadores na saúde e na qualidade geral de vida da população. (FRANCA; CARDOSO NETO, 2006, p. 26-27).

Segundo Christofidis (2006, p. 46), se a oferta de água renovável do país for menor que 4.650 litros por pessoa/dia $(1.700 \mathrm{~m} 3 / \mathrm{hab}$. ano), pode-se afirmar que esta região encontra-se na condição de "escassez hídrica". Se a disponibilidade estiver abaixo de 2.740 
litros por pessoa/dia ( $1.000 \mathrm{~m} 3 / \mathrm{hab}$. ano), ocorre "escassez crônica" de água, situação em que não há folga para uso de água em produção agrícola, pecuária e industrial, em quantidade que permita o comércio em maior escala, a não ser com alta tecnologia de uso e boa gestão.

Como a quantidade e a qualidade da água estão sendo afetadas pela inadequada ação do ser humano, deve-se estabelecer a proteçáo da vegetaçáo e dos solos de forma a que possibilitem os fluxos de água, sua forma natural de movimentação e de filtração e, ao mesmo tempo, definam-se as finalidades que são mais importantes (as prioridades) e os limites de uso, criando-se as condiçōes de convivência entre usuários e ecossistemas, tanto em quantidade como em qualidade de água disponível (CHRISTOFIDIS, 2006, p. 46).

A escassez de água também é agravada pelo desperdício devido às falhas estruturais nos sistemas de distribuição e abastecimento. Segundo Lobel (2015), o relatório (concluído em dezembro de 2014) do Sistema Nacional de Informaçôes de Saneamento Básico do Ministério das Cidades o índice de perda de água tratada é de 37\%. Registra ainda um aumento do consumo de água "per capita" na maioria dos Estados brasileiros.

Com o objetivo de minimizar os problemas de desperdício da água tratada pelas concessionárias ou permissionárias dos serviços públicos de distribuição e abastecimento de água potável está em tramitação na Câmara dos Deputados o Projeto de Lei no 6402, de 2013 de autoria do Deputado Federal Marco Tebaldi (PSDB-SC). A justificativa é em razão da baixa capacidade institucional e de gestáo dos sistemas e a pouca disponibilidade de recursos para investimentos se deve à falta de açôes na rede de distribuição e a ampliação do sistema sem os devidos estudos de engenharia. A maioria das redes é, na prática, uma mistura de tubos de diferentes tipos de materiais, assentados ao longo de várias décadas e que geralmente apresentam sinais de deterioraçáo em maior ou menor escala conforme a idade de assentamento, material do tubo, técnicas de instalação e as características do solo.

O texto do Projeto de Lei no 6402/2013 estabelece a obrigatoriedade do cumprimento de metas na redução no índice de perdas pelas empresas de distribuição e abastecimento de água tratada.

Art. 2º Torna obrigatória, as concessionárias ou permissionárias dos serviços públicos de distribuição e abastecimento de água potável, em todo o território nacional após a vigência desta legislação, o cumprimento das seguintes metas:

I - atingir o Índice de Perdas por Ligação em 30\% (1/lig.dia) nos primeiros 05 (cinco) anos de vigência desta legislação;

II - atingir o Índice de Perdas por Ligação em 20\% (1/lig.dia) em 10 (dez) anos de vigência desta legislação; 
III - manter o Índice de Perdas por Ligação em 15\% (1/lig.dia) após 15 (quinze) anos de vigência desta legislação.

E ainda preceitua que:

Art. $3^{\circ}$. Fica ao Ministério das Cidades juntos às agências reguladoras de controle e fiscalização dos serviços de abastecimento de água, esgotamento e sanitário, da União, Distrito Federal, Estados e Municípios, a responsabilidade pela normatização, fiscalização e punição.

Art. $4^{\mathrm{o}}$. É vedada a criação ou majoração de tarifas de qualquer natureza para aplicação do disposto desta legislação.

Em cada dez municípios, com mais de 100.000 habitantes, seis registraram perdas de volumes de água entre $20 \%$ a 50\%. O Brasil ainda perde $37 \%$ a $42 \%$ do total de sua água tratada e distribuída por erros estruturais no sistema, gerando prejuízo de 7,4 bilhóes de dólares ao ano. O relatório do IBGE mostra que o Brasil desperdiça aproximadamente 45\% da água tratada captada pelas companhias antes de chegar às torneiras dos brasileiros, onde o prejuízo passa de R \$4 bilhóes por ano (ATLAS DE SANEAMENTO, 2011).

Outra justificativa apresentada no Projeto de Lei no 6402/2013 é no sentido de que o desperdício de água representa um dos maiores desafios e dificuldade para a expansão das redes de distribuição de água no Brasil, mas reduzir o desperdício não é importante apenas para a economia das concessionárias, mas para o consumidor, além de ser uma atitude importante também para não haver um desabastecimento devido aos vazamentos nas redes de distribuição.

Tundisi; Tundisi (2009, p. 94-95) enumeram outras estratégias para enfrentar a escassez da água, seja por falta de disponibilidade (problema de deficiência do ciclo hidrológico), seja por excesso de poluição (com aumento excessivo dos custos do tratamento) que são:

1. Criar alternativas para obtenção de mais água: aumentar as reservas, proteger os aquíferos subterrâneos e promover o transporte de água para onde há escassez. Proteção dos mananciais de águas superficiais é parte dessa estratégia; dessalinização é outra opção, mas ainda relativamente cara. Seus custos podem baixar nos próximos dez anos, tornando este processo mais viável (atualmente os custos oscilam entre US\$ 0,50 a US\$1,00 por metro cúbico de água doce produzida a partir de água salgada). A transposição de águas deve ser feita com extensos cuidados e análises de impacto, inclusive com avaliação de impacto após a transposição.

2. Diminuir o consumo e reciclar a água. É fundamental reduzir a demanda de água, estabelecendo cobranças para o uso, taxando poluidores e estimulando o 
reuso. Novas técnicas para usos múltiplos devem ser pesquisadas e implementadas.

3. Ampliar a capacidade de gerenciamento integrado: reduzir a poluição, gerenciar usos múltiplos, promover monitoramento avançado, reduzir o desperdício e sobretudo educar a população em geral e os tomadores de decisão (políticos, prefeitos, gerentes). O problema de água deve fazer parte de programas mobilizadores, que promovam a percepção da população sobre o problema e estimulem sua participação efetiva nas decisóes estratégicas.

\section{Direitos Fundamentais e Acesso à Água Potável}

Para Canotilho (2003, p. 1239) os direitos fundamentais são categorias dogmáticas e, além disso, garantias contramajoritárias que se constroem como exercícios de direitos que se revelam possíveis dentro da dogmática. Na mesma linha, Bello Filho (2012, p. 1) entende que direitos fundamentais são categorias dogmáticas e possuem toda uma estrutura dogmática que os justifica e fornece as condiçóes necessárias para que se tornem efetivos a partir de uma norma de matriz constitucional como, por exemplo, o art. $225 \mathrm{da}$ Constituição Federal que tutela a preservação ambiental como um valor irradiante para todo o ordenamento jurídico.

Viegas (2012, p. 25) entende que, pelo fato de o acesso à água ter sintonia estreita com direitos fundamentais como a vida, a saúde e a dignidade da pessoa humana, assume inegável contorno também de direito fundamental, que reside no direito de utilização de água em quantidade e qualidade adequadas. Também para Irigaray (2003, p. 398) enquanto direito fundamental, o direito à água é inalienável e irrenunciável, e o exercício da cidadania ensejará, ao longo do tempo, uma ampliação desse direito, incompatibilizando seu exercício com a gestão meramente econômica da água. Acresçase que não é possível a concretização da democracia dissociada da implementação dos direitos fundamentais.

Mirandola; Sampaio (2006, p. 265-266), ressaltam ainda que a água é direito fundamental que apresenta quatro dimensóes essenciais: a dimensão humanitária e de dignidade humana que implica criar condições de acesso a um mínimo de água, necessária à sobrevivência humana; a dimensão econômica nos remete à ideia de água como bem natural limitado quanti-qualitativamente, sendo necessária a sua exploração grandes investimentos econômicos; numa dimensão social a "água é fator de inclusão"; e, por fim, a dimensão sanitária nos lembra de que não basta à disponibilidade de uma quantidade mínima de água, pois, a "água deve ser limpa”, ou seja, não poluída, inclusive, por uma questão de saúde pública. 
Portanto, mesmo que a escassez quanti-qualitativa da água atribua a esta valor econômico, em momento algum pode ser tratada como mercadoria, pois, direito fundamental por excelência (SARLET, 2003, p. 84). O reconhecimento da água como direito fundamental é mais do que uma implicação teórica, mas uma reflexão de cunho teórico e efeito prático. Onde, primeiro passo, é estabelecer uma política efetiva de universalizaçáo de direito à água (MIRANDOLA; SAMPAIO, 2006, p. 266-267).

Sarlet (2003, p. 84) assevera que existem direitos fundamentais universais e consensuais, dentre os quais o direito à água e o respeito à dignidade humana. Nesse sentido, o constituinte brasileiro, inspirado em constituiçôes ocidentais sociais democratas do século anterior, inscreveu em seu art. $1^{\circ}$, inciso III, o postulado da dignidade da pessoa humana entre os fundamentos da organização nacional.

De fato, pode-se afirmar que o Estado Democrático da atualidade é um Estado de abertura constitucional radicado no princípio da dignidade do ser humano, tendo-o como eixo central. Trata-se, pois, do constitucionalismo das comunidades humanas, mais orgânico e voltado mais para a sociedade do que para o Estado (LEITE; BELCHIOR, 2014, p. 12). Sendo o Estado Democrático de Direito a fórmula política adotada pelo constituinte originário de 1988, segundo disposto no art. 1ª "caput", da Constituiçáo Federal, Guerra Filho (2003, p. 20) afirma que toda interpretação do texto constitucional deve ser no sentido de lhe conferir o máximo de eficácia, apresentando-se como um programa de ação a ser partilhado por todo integrante da comunidade política.

Dessa forma, assegurar o respeito da dignidade humana continua sendo o fim da sociedade política. Dignidade esta que não é vista apenas no âmbito do indivíduo isolado, mas sim de uma forma coletiva, em virtude da solidariedade. Por conta disso, surgem direitos de titularidade coletiva, intitulados pela doutrina de direitos fundamentais de terceira dimensão que consagram o princípio da solidariedade, englobando, também, o meio ambiente ecologicamente equilibrado, uma saudável qualidade de vida e outros direitos difusos (LEITE; BELCHIOR, 2014, p. 12-13).

A Constituição Brasileira de 1988, ao assegurar a proteção do meio ambiente em seu art. 225, fortalece o princípio da função ecológica da propriedade, impondo obrigaçóes positivas e negativas ao proprietário, à luz do princípio da solidariedade. Fala-se, inclusive, em dimensão ecológica na dignidade humana, o que implica numa matriz fundante dos demais direitos fundamentais (LEITE; BELCHIOR, 2014, p. 13-17), (FENSTERSEIFER, 2008, p. 35). Assim, reconhecer a água como direito fundamental consiste em atribuir ao Estado o dever de garantir um mínimo essencial à sadia qualidade de vida, das presentes e futuras geraçóes.

Porém, mais do que reconhecer a água como direito fundamental é necessária uma gestão participativa, efetiva e eficaz. Isso porque, como anota Benjamin (2011, p. 113), a 
tutela ambiental não é um daqueles valores sociais em que basta assegurar uma liberdade negativa, orientada a rejeitar a intervenção ilegítima ou do abuso do Estado, mas um conjunto de deveres positivos (obrigação de fazer) e deveres negativos (obrigação de nãofazer). No Brasil, o fornecimento de água potável, pela União, Estados e Municípios é ato administrativo vinculado, devendo ser observado o conjunto de medidas necessárias para implementação (MACHADO, 2001, p. 16).

Nesse sentido, Leite; Ferreira (2010, p. 15) defendem a possibilidade de participação dos cidadãos nos processos ambientalmente relevantes surge não apenas como consequência do direito de proteger interesses fundamentais que são transindividuais, mas também como resultado do reconhecimento de que a preservação do meio ambiente, considerado em sua dimensão integrada, deve articular-se de forma integrativa e, portanto, compartilhada.

Deve ser ainda lembrado que, em sua compreensão alargada, o direito fundamental à água interessa a todos os membros da coletividade, em uma perspectiva intergeracional e multicultural, uma vez que afirma o valor múltiplo da água, ressaltando que há direitos incidentes sobre os recursos hídricos que remontam a manifestações tradicionais e expressôes particulares e próprias de uma identidade cultural (arts. 216, "caput"; 225, "caput" e 231, "caput", da CF). Portanto, o direito à água é imprescritível e atribuído a toda a coletividade, sendo que a forma tradicional com que os membros dessa coletividade se relacionam perante a água, através do acesso, uso, gestão e destinação, por si só, também se encontra sob a proteção desse direito (AYALA, 2012, p. 330-331).

Fachin; Silva (2012, p. 74-76), defendem a existência de uma sexta dimensão de direitos fundamentais. A água potável, componente do meio ambiente ecologicamente equilibrado, merece ser destacada e alçada a um plano que justifique o nascimento de uma nova dimensão de direitos fundamentais. $\mathrm{O}$ acesso à água potável é um direito fundamental. Nessa condição, ele necessita receber expressa proteção jurídica. Tal proteção deve estar primeiramente na Constituição Federal, porquanto esta é o "locus" específico para abranger tais direitos. Registre-se que a Constituição brasileira, promulgada em 05 de outubro de 1988, não inseriu o direito de acesso à água potável expressamente no catálogo específico dos direitos e garantias fundamentais (arts $5^{\circ}$ a $17^{\circ}$ ); contudo esta omissão não impede que o mencionado direito seja compreendido como fundamental.

A inclusão do acesso à água entre os direitos sociais está em análise na Câmara dos Deputados em duas propostas de emenda à Constituição. A primeira denominada PEC no 39 de 2007 de autoria do Deputado Raimundo Gomes de Matos (PSDB-CE) e outros já foi aprovada na Comissão de Constituição e Justiça e de Cidadania em 01 de abril de 2014 e será analisada por uma Comissão Especial a ser criada para essa finalidade. Em seu texto ela dá nova redação ao art. $6^{\circ}$ da Constituição Federal que passaria a vigorar com a seguinte redação: 
Art. 6º São direitos sociais a educação, a saúde, o trabalho, a moradia, a água, o lazer, a segurança, a previdência, a assistência aos desamparados, na forma desta Constituição. (Grifo nosso)

A justificativa da PEC no 39/2007 é no sentido de que da mesma forma como se reconhece o direito à alimentação, à moradia, ao lazer, à saúde, à educação, o acesso à água potável e de boa qualidade, também, é um direito fundamental porque está intimamente relacionada com o direito à vida. O direito à água é, portanto, um direito humano. A água deve, então, ser, antes de tudo, considerada um bem social e não um bem econômico, porque como bem econômico ela é passível de transaçóes comerciais e o preço poderia se constituir em barreira à utilizaçáo desse bem essencial pelos mais pobres ou onerar, significativamente, os orçamentos familiares, comprometendo, assim, a qualidade de vida das pessoas.

Acrescenta ainda que, o direito à água não é, porém, um direito ilimitado. Restringese a uma quantidade suficiente para garantir as necessidades básicas da pessoa humana. Estudos efetuados pelo Banco Mundial e Organização Mundial de Saúde sugerem que "a quantidade de água recomendada por pessoa varia entre 20 e 40 litros/dia, náo incluindose água para cozinhar e para a limpeza básica. Isto significa que cada ser humano teria o direito a receber, pelo menos, 40 litros/dia de água potável, independentemente de qualquer pagamento". Outros estudos sugerem como "padrão mínimo o fornecimento gratuito de 50 litros/dia, sendo 5 litros para dessedentação, 20 litros para serviços sanitários, 15 litros para banho e 10 para cozinhar".

A segunda proposta denominada PEC no 213 de 2012 de autoria da Deputada Janete Rocha Pietá (PT-SP) e outros foi aprovada na Comissão de Constituição e Justiça e de Cidadania em 01 de abril de 2014 e será analisada conjuntamente com a PEC no 39/2007 por uma Comissão Especial a ser criada para esse objetivo. A PEC no 213/2012 também pretende incluir a água como direito social.

$\mathrm{O}$ art. $6^{\circ}$ da Constituição Federal passaria a vigorar com o seguinte texto:

Art. $6^{\circ}$. São direitos sociais o acesso à água, a educação, a saúde, a alimentação, o trabalho, a moradia, o lazer, a segurança, a previdência social, a proteção à maternidade e à infância, a assistência aos desamparados, na forma desta Constituição. (Grifo nosso)

Na exposição de motivos faz abordagem da Constituição Federal que atribui à água a condição de bem estatal, um bem público a que todos têm direito e acesso, porém, a legislação federal será enriquecida com a caracterização da água como um bem de função social. A gestão dos recursos hídricos, como função social para desenvolvimento sustentável, é uma solução que vem sendo apresentada para o uso eficiente. O Brasil tem 12\% da água doce mundial, o que significa que temos o maior potencial hídrico do planeta. Esse 
fato transfere para nós a responsabilidade de gerir, distribuir e preservar este recurso que é tão almejado por vários povos da Terra. A água é essencial à vida, devendo ser considerado item básico de consumo, um direito social. Com isso deve, ser disponibilizada para todos os cidadãos, potável e com qualidade.

Assevera ainda que, os benefícios do consumo diário de água potável para a saúde são inúmeros. Fonte de energia vital, a água é rica em sais minerais e é considerada o principal hidratante para o corpo, estimulando o bom funcionamento do organismo. $\mathrm{O}$ seu tratamento deve ser uma preocupação constante para evitar a presença de elementos nocivos à saúde, a contaminação e o surgimento de doenças. Além do mais, hoje a água é tida como o bem mais precioso e, por meio dela, é que se produzem e se reproduzem todos os elementos essenciais para a existência no planeta.

\section{Conclusões}

1. A água é elemento fundamental para a vida. É um recurso natural, renovável. Ainda, caracteriza-se por ser encontrada de forma abundante na superfície terrestre. No entanto, em várias regiôes a escassez de água é crônica. Em outras, há faltas sazonais de recursos hídricos e racionamentos. Além disso, destaca-se entre outros fatores,o aumento progressivo da populaçáo e o crescimento dos centros urbanos, que interferem no meio ambiente poluindo as águas, em razão da falta de saneamento básico, infraestrutura e ocupação de áreas irregulares. Também, diante da falta de consciência ambiental, a população desperdiça, cotidianamente, quantia significativa de águas próprias para o consumo das presentes e futuras gerações. Registra-se, ainda, a ausência de gerenciamento e fiscalização dos sistemas legais e administrativos de gestão dos recursos hídricos em esfera local, nacional e supranacional, a partir da inação da comunidade, da sociedade e do poder público, colabora para a diminuição da água potável no mundo e majora os efeitos da crise da água (SANTIN; DALLA CORTE, 2013, p. 26-27).

2. O direito subjetivo à água não é apenas o bastante para sobreviver. O Direito vai além quando resguarda o mínimo existencial. Esse mínimo deve proporcionar uma vida com dignidade. É por isso que o direito humano fundamental abrange o acesso à água em quantidade e qualidade adequadas para uma vida digna (VIEGAS, 2012, p. 16).

3. O conteúdo do direito fundamental ao meio ambiente ecologicamente equilibrado, conforme disposto no "caput" do art. 225 da Constituição Federal, permite aproximar o ordenamento jurídico brasileiro dos pressupostos indispensáveis à edificação do Estado de direito ambiental que a despeito do seu caráter abstrato e imaginário, não se deve desconsiderar a relevância do paradigma proposto para uma melhor compreensão das novas exigências impostas pela sociedade moderna (LEITE; FERREIRA, 2010, p. 28). 
4. A escassez quali-quantitativa de água doce é fato. A gênese da crise hídrica está na postura antropocêntrica. $\mathrm{O}$ homem, como único ser racional, vê-se fora do meio ambiente e num plano superior. Os reflexos dessa postura atingem o ser humano, que, ao lado dos demais organismos vivos, sofre com a insuficiência de água ou com sua qualidade deficiente. $\mathrm{O}$ acesso à água em quantidade suficiente e qualidade adequada é um direito humano fundamental. A função primordial do Estado é a satisfação do bem-estar social. Dela decorrem suas atribuições mais específicas. Para que a sociedade possa gozar de uma vida digna e com saúde, deve ter acesso adequado à água potável.Nesse ponto, impóe-se um novo paradigma alicerçado com um olhar ecocêntrico para combater adequadamente a crise da água (VIEGAS, 2012, p. 160-161).

5. Os princípios da prevenção e da precaução são igualmente incidentes na gestão da água. A prevenção contra danos ambientais protege os recursos hídricos. Como há uma interligação entre todas as estruturas que compóem o Planeta, qualquer forma de prevenção ambiental contribui ao menos para estabilizar o problema da escassez hídrica (VIEGAS, 2012, p. 163).

\section{Referências}

ADEDE Y CASTRO, João Marcos. Água um direito humano fundamental. Porto Alegre: Nuria Fabris Editora, 2008.

ATLAS DE SANEAMENTO. Ministério do Planejamento, Orçamento e Gestão. In: Instituto Brasileiro de Geografia e Estatística - IBGE. Rio de Janeiro, 2011. Disponível em: <http://www.ibge.gov.br/home/estatística/populacao/Atlas_saneamento/ default_zip.shtm> Acesso em: 21 jan. 2015.

AYALA, Patryck de Araújo. Deveres ecológicos e regulamentação da atividade econômica na Constituição brasileira. In: CANOTILHO, José Joaquim Gomes; LEITE, José Rubens Morato (Org.). Direito constitucional ambiental brasileiro. 5. ed. São Paulo: Saraiva, 2012.

BECK, Ulrich. La sociedad del riesgo: hacia una nueva modernidad. Tradução de Jorge Navarro, Daniel Jiménez e Maria Rosa Borrás. Barcelona: Paidós, 1998.

BELLO FILHO, Ney de Barros. Direito ao ambiente: da compreensão dogmática do direito fundamental na pós-modernidade. São Paulo: Livraria do Advogado. 2012.

BELLVER CAPELLA, Vicente. Ecologia: de las razones a los derechos. Granada: Ecorama, 1994.

BENJAMIN, Antônio Herman. Direito constitucional ambiental brasileiro. In: CANOTILHO, José Joaquim Gomes; LEITE, José Rubens Morato (Org.). Direito constitucional ambiental brasileiro. 4. ed. São Paulo: Saraiva, 2011. 
BIANCHI, Patrícia. Eficácia das normas ambientais. São Paulo: Saraiva, 2010.

BORATTI, Larissa Verri. Risco ambiental no espaço urbano: aspectos teórico-jurídicos. In: FERREIRA, Heline Sivini; LEITE, José Rubens Morato; BORATTI, Larissa Verri (org.). Estado de direito ambiental: tendências. 2. ed. Rio de Janeiro: Forense Universitária, 2010.

BRASIL. Agenda 21 brasileira: resultado da consulta nacional / Comissão de Políticas de Desenvolvimento Sustentável e da Agenda 21 Nacional. 2. ed. Brasília: Ministério do Meio Ambiente, 2004.

BRASIL. Constituição Federal. Constituição da República Federativa do Brasil de 1988. Publicada no Diário Oficial da União, Brasília, 05 out. 1988. Disponível em: <http://www.planalto.gov.br/ccivil_03/constituicao/constituicaocompilado.htm>. Acesso em: 11 fev. 2015.

BRASIL. Decreto no 24643, de 10 de julho de 1934. Decreta o Código de Águas. Publicado no Diário Oficial da União, Brasília, 27 jul. 1934. Disponível em: <http:// www.planalto.gov.br/ccivil_03/decreto/d24643.htm>. Acesso em 29 dez. 2014.

BRASIL. Lei no 9605, de 12 de fevereiro de 1998. Dispóe sobre as sançóes penais e administrativas derivadas de condutas e atividades lesivas ao meio ambiente. Publicada no Diário Oficial da União, Brasília, 17 fev. 1998. Disponível em: <http://www. planalto.gov.br/ccivil_03/leis/19605.htm>. Acesso em 26 mar. 2014.

BRASIL. Lei no 9984, de 17 de julho de 2000. Dispóe sobre a criação da Agência Nacional de Águas - ANA, entidade federal de implementação da Política Nacional de Recursos Hídricos e de coordenação do Sistema Nacional de Gerenciamento de Recursos Hídricos, e dá outras providências. Publicada no Diário Oficial da União, Brasília, 18 jul. 2000. Disponível em: <http://www.planalto.gov.br/ccivil_03/leis/ 19984.htm>. Acesso em 29 dez. 2014.

BRASIL. Lei no 9985, de 18 de julho de 2000. Regulamenta o art. 225, $\$ 1^{\circ}$, incisos I, II, III e VII da Constituição Federal, institui o Sistema Nacional de Unidades de Conservação da Natureza e dá outras providências. Publicada no Diário Oficial da União, Brasília, 19 jul. 2000. Disponível em: <http://www.planalto.gov.br/ccivil_03/leis/ 19985.htm>. Acesso em 29 dez. 2014.

BRASIL. Lei no 10257, de 10 de julho de 2001. Dispóe sobre o Estatuto da Cidade. Publicada no Diário Oficial da Uniáo, Brasília, 11 jul. 2001. Disponível em: <http:// www.planalto.gov.br/ccivil_03/leis/leis_2001/110257.htm>. Acesso em 29 dez. 2014.

BRASIL. Lei no 10406, de 10 de janeiro de 2002. Institui o Código Civil. Publicada no Diário Oficial da União, Brasília, 11 jan. 2002. Disponível em: <http://www.planalto.gov.br/ccivil_03/leis/2002/110406.htm>. Acesso em 14 fev. 2015. 
BRASIL. Câmara dos Deputados. Projeto de Lei no 6402 de 2013. Dispóe sobre a redução no índice de perdas pelas concessionárias ou permissionárias dos serviços públicos de distribuição e abastecimento de água potável, e dá outras providencias. Disponível em: <http://www.camara.gov.br/proposicoesWeb/fichadetramitacao?idProposicao=592985>. Acesso em 14 fev. 2015. Texto original.

BRASIL. Câmara dos Deputados. PEC no 39 de 2007. Dá nova redação ao art. 6º da Constituição Federal. Disponível em: <http://www.camara.gov.br/proposicoesWeb/ fichadetramitacao?idProposicao=347951 >. Acesso em 28 jan. 2015. Texto original.

BRASIL. Câmara dos Deputados. PEC no 213 de 2012. Dá nova redação ao art. 6º da Constituição Federal, para incluir o acesso à água como um direito social. Disponível em: <http://www.camara.gov.br/proposicoesWeb/fichadetramitacao?idProposicao $=558401>$. Acesso em 28 jan. 2015. Texto original.

BRASIL. SUPERIOR TRIBUNAL DE JUSTIÇA. REsp 1.109.778/SC (2008/0282805-

2), Relator Ministro Herman Benjamin, Segunda Turma, DJ 04.05. 2011.

CANOTILHO, José Joaquim Gomes. Direito constitucional e teoria da constituição. 7. ed. Coimbra: Almedina, 2003.

CANOTILHO, José Joaquim Gomes. Estado constitucional ecológico e democracia sustentada. In: FERREIRA, Heline Sivini; LEITE, José Rubens Morato (Coord.). Estado de direito ambiental: tendências, aspectos constitucionais e diagnósticos. Rio de Janeiro: Forense Universitária, 2004.

CANOTILHO, José Joaquim Gomes. Direito constitucional ambiental português: tentativa de compreensão de 30 anos das geraçóes ambientais no direito constitucional português. In: CANOTILHO, José Joaquim Gomes; LEITE, José Rubens Morato (Org.). Direito constitucional ambiental brasileiro. 4. ed. São Paulo: Saraiva, 2011.

CARSON, Rachel. Primavera silenciosa. Tradução de Claudia Sant'Anna Martins. 1. ed. São Paulo: Gaia, 2010.

CHRISTOFIDIS, Demetrios. Água e agricultura. In: Revista Plenarium: os múltiplos desafios da água. Brasília: Câmara dos Deputados, ano III, no 3, set. 2006.

CRUZ, Fernando Castro da. Das águas: sua importância no novo milênio. Belo Horizonte: Editora Palpite. 2001.

DALLA CORTE, Thaís; PORTANOVA, Rogério Silva. A evolução do tratamento jurídico das águas: direito humano e patrimônio comum da humanidade. In: SOUZA, Maria Cláudia da Silva Antunes; FIORILLO, Celso Antônio Pacheco; YOSHIDA, Consuelo Yatsuda Moromizato (Coord.). Direito Ambiental II. XXII Congresso Nacional do CONPEDI/UNINOVE. Florianópolis: FUNJAB, 2013. 
DECLARAÇÃO de Dublin (1992). Disponível em: <http://www.meioambiente.uerj.br/ emrevista/documentos/dublin.htm>. Acesso em: 18 abr. 2014.

DEMAJOROVIC, Jacques. Sociedade de risco e responsabilidade socioambiental: perspectivas para a educação corporativa. São Paulo: Editora Senac, 2003.

FACHIN, Zulmar; SILVA, Deise Marcelino da. Acesso à água potável: direito fundamental de sexta geração. São Paulo. Millennium Editora. 2010.

FACHIN, Zulmar; SILVA, Deise Marcelino da. Acesso à água potável: direito fundamental de sexta dimensão. 2. ed. Campinas: Millennium Editora, 2012.

FRANCA, Dalvino Troccoli; CARDOSO NETO, Antônio. Água e sociedade. In: Revista Plenarium: os múltiplos desafios da água. Brasília: Câmara dos Deputados, ano III, no 3, set. 2006.

FARIAS, Paulo José Leite. Água: bem jurídico econômico ou ecológico? Brasília: Brasília Jurídica. 2005.

FENSTERSEIFER, Tiago. Direitos fundamentais e proteção do meio ambiente: a dimensão ecológica da dignidade humana no marco jurídico-constitucional do Estado socioambiental de direito. Porto Alegre: Livraria do Advogado, 2008.

FERRARESI, Priscila. Justiça constitucional e a governança ambiental. In: Revista Brasileira de Políticas Públicas, Brasília, vol. 1, no 2, jul./dez. 2011.

FERREIRA. Luciane. Do acesso à água e do seu reconhecimento como direito humano. In: Revista de Direito Público, Londrina, vol. 6, no 1, jan./abr., 2011.

GLASENAPP, Maikon Cristiano; CRUZ, Paulo Márcio. Estado e sociedade nos espaços de governança ambiental transnacional. In: Revista Direito Econômico Socioambiental, Curitiba, vol. 2, no 1, jan./jun. 2011.

GRAF, Ana Cláudia Bento. A tutela dos estados sobre as águas. In: FREITAS, Vladimir Passos de (Coord.). Águas: aspectos jurídicos e ambientais. 3. ed. Curitiba: Juruá, 2008.

GRANZIERA, Maria Luiza Machado. Direito de águas: disciplina jurídica das águas doces. 3. ed. São Paulo: Atlas, 2006.

GUERRA FILHO, Willis Santiago. Processo constitucional e direitos fundamentais. 3. ed. São Paulo: Celso Bastos Editor, 2003.

HÄBERLE, Peter. El Estado constitucional. Tradução de Héctor Fiz-Fierro. Lima: Fondo Editorial de la Pontificia Universidad Católica del Perú, 2003.

IRIGARAY, Carlos Teodoro Hugueney. Água: um direito fundamental ou uma mercadoria? In: BENJAMIN, Antonio Herman (Org.) Congresso internacional de direito ambiental: direito, água e vida. São Paulo: Imprensa Oficial, 2003, vol. 1. 
LEITE, José Rubens Morato; FERREIRA, Heline Sivini. Tendências e perspectivas do Estado de direito ambiental no Brasil. In: FERREIRA, Heline Sivini; LEITE, José Rubens Morato; BORATTI, Larissa Verri (Org.) Estado de direito ambiental: tendências.. 2. ed. Rio de Janeiro: Forense Universitária, 2010.

LEITE, José Rubens Morato; BELCHIOR, Germana Parente Neiva. Direito constitucional ambiental brasileiro. In: MORATO, José Rubens; PERALTA, Carlos E. (Org.) Perspectivas e desafios para a proteção da biodiversidade no Brasil e na Costa Rica. São Paulo: Editor Instituto O direito por um planeta verde, 2014.

LOBEL, Fabrício. Brasil desperdiça 37\% da água tratada, aponta relatório do governo federal. In: Folha de São Paulo. Publicação datada de: 21 jan. 2015. Disponível em: <http://www1.folha.uol.com.br/cotidiano/2015/01/1578007-brasil-desperdica37-da-agua-tratada-apon ta-relatorio-do-governo-federal.shtml> Acesso em: 21 jan. 2015 .

LOVELOCK, James. A vingança de gaia. Tradução de Ivo Korytowski. Rio de Janeiro: Intrínseca, 2006.

MACHADO, Paulo Affonso Leme. Recursos hidricos: direito brasileiro e internacional. São Paulo: Malheiros, 2002.

MACHADO, Paulo Affonso Leme. Direito ambiental brasileiro. 9. ed. São Paulo: Malheiros, 2001.

MIRANDOLA, Carlos Maurício Sakata; SAMPAIO, Luiza Saito. Universalização do direito à água. In: BARRAL, Walter; PIMENTEL, Luiz Otávio (Org.) Direito ambiental e desenvolvimento. Florianópolis: Fundação Boiteux, 2006.

OST, François. A natureza à margem da lei: a ecologia à prova do direito. Tradução de Joana Chaves. Lisboa: Piaget, 1997.

PETRELLA, Riccardo. O manifesto da água: argumentos para um contrato mundial. Tradução de Vera Lucia Mello Joscelyne. Petrópolis-Rio de Janeiro: Vozes, 2002.

PINTO, Elizabeth Machado. A gestão de recursos hídricos e as interferências do sistema urbano: município de Queimados-RJ. In: Revista da Universidade Rural de Seropédica. Rio de Janeiro, $\mathrm{n}^{\circ}$ 1, vol. 29, 2007.

POMPEU, Cid Tomanik. Águas doces no Brasil: capital ecológico, uso e conservação. São Paulo: Escrituras, 1999.

POMPEU, Cid Tomanik. Direito de águas no Brasil. 2. ed. São Paulo: Revista dos Tribunais, 2010.

PUREZA, José Manuel. Tribunais, natureza e sociedade: o direito do ambiente em Portugal. Lisboa: Cadernos do Centro de Estudos Judiciários, 1996. 
SANTIN, Janaína Rigo; DALLA CORTE, Thaís. O direito das águas subterrâneas no Brasil, no Mercosul e na Uniâo Europeia: um estudo comparado. Santa Maria: Editora UFSM, 2013.

SANTOS, Antônio Silveira Ribeiro dos. Município e a gestão hidrica. Disponível em: <http://www.aultimaarcadenoe.com/artigo56.htm>. Acesso em 28 mai. 2014.

SARLET, Ingo Wolfgang. A eficácia dos direitos fundamentais. 3. ed. Porto Alegre: Livraria do Advogado, 2003.

SETTI, Arnaldo Augusto. Introdução ao gerenciamento de recursos hidricos. 3 ed. Brasília: Agência Nacional de Energia Elétrica/Agência Nacional de Águas, 2001.

STEIGLEDER, Anelise Monteiro. Discricionariedade administrativa e dever de proteção do ambiente. In: Revista do Ministério do Estado do Rio Grande do Sul, no 48, jul.-set. 2002.

TUNDISI, José Galizia; TUNDISI, Takako Matsumura. A água. 2. ed. São Paulo: Publifolha, 2009 (Folha Explica).

VERBICARO, Loiane Prado. Um estudo sobre as condiçóes facilitadoras da judicialização da política no Brasil. In: Revista de Direito GV, São Paulo, vol. 4, no 2, jul.-dez. 2008.

VIEGAS, Eduardo Coral. Visão jurídica da água. 2. ed. Porto Alegre: Livraria do Advogado, 2012.

VIOLA, Eduardo J. Evolução da mudança climática na agenda internacional e transição para uma economia de baixo carbono, 1990-2009. In: FERREIRA, Heline Sivini; MORATO, José Rubens; BORATTI, Larissa Verri (org.). Estado de direito ambiental: tendências. 2. ed. Rio de Janeiro: Forense Universitária, 2010.

WOLKMER, Maria de Fátima Schumacher; PAULITSCH, Nicole da Silva. O Estado de Direito Socioambiental e a governança ambiental: ponderaçóes acerca da judicialização das políticas públicas ambientais e da atuação do Poder Judiciário. In: Revista NEJ - Eletrônica, vol. 18, nº 2, mai.-ago. 2013. 